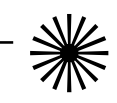

\title{
PENSAR BRASIL CON Y ENTRE
}

\author{
IMÁGENES
}

\author{
RESENHA \\ MARTINS, Luciana. Photography and documentary film in \\ the making of modern Brazil. Manchester: Manchester \\ University Press, 2013.
}

- VERÔNICA HOLLMAN'

Una imagen, o mejor dicho, el encuentro de la mirada avezada de Luciana Martins con una lámina expuesta en el Museu do Índio funciona como una fructífera apertura para el libro Photography and documentary film in the making of modern Brazil. En la introducción, Luciana Martins se vale de aquella lámina para trazar las coordenadas que le permitirán desplegar otras potencias de las imágenes e iniciar un lúcido recorrido sobre las relaciones entre las tecnologías de la visión, lo nacional y la modernidad. La obra confirma que con y entre las imágenes es posible pensar e interpretar el Brasil de la primera mitad del siglo XX. La contribución se extiende a las propias tecnologías de la visión en las trayectorias y las reconfiguraciones que imprimen las tensiones local/nacional/global. 
El libro se inscribe en el campo de estudios visuales al problematizar las imágenes desde diversas dimensiones: aquello que dan a ver (o invisibilizan), sus formas de producción y circulación en sus anclajes espaciales y temporales. También da continuidad a una serie de valiosas publicaciones en idioma inglés que examinan las imágenes como órdenes visuales, capaces de moldear el espacio latinoamericano e incluso nuestros modos de entenderlo ${ }^{2}$. Los modos de mirar las imágenes, una de las preocupaciones centrales de los estudios visuales, tal vez sea uno de los puntos que queda en suspenso en este libro.

La obra se estructura a través de siete casos que, a modo de episodios, podrían ser leídos sin seguir el orden previsto por la autora. Sin embargo, en esa secuencia el lector encontrará las conexiones que con sutiles pinceladas se van trazando entre los casos. En cada uno de ellos, Luciana Martins emprende una doble tarea que, con rigurosidad y sagacidad, moldea el propio corpus y su análisis. En primer lugar, el universo de imágenes de personas y paisajes brasileños de las cuatro primeras décadas del siglo $\mathrm{XX}$ resulta de un minucioso $\mathrm{y}$ exhaustivo trabajo de archivo en los acervos de la British Library, Birkbeck Library, Senate House Library, Royal Anthropological Institute, Royal Geography Society, American Geographical Society, Instituto de Estudos Brasileiros, Cinemateca Brasileira, Museu do Índio, Casa de Oswaldo Cruz, Museu Amazónico, Bibliothèque nationale de France, Daisy Njoku of the Human Studies Film Archives, Smithsonian Institution además de colecciones personales y privadas. De este modo, la obra acerca una selección de registros visuales de difícil acceso. En segundo lugar, cada episodio constituye un cuidadoso montaje de imágenes que, como apunta el historiador del arte Georges Didí-Huberman, es una “actividad en que la imaginación se convierte en una técnica de 
producir pensamiento en el ritmo incesante de las diferencias y de las relaciones" (2008: 295). Luciana Martins recorta, desplaza, agrupa y ordena ese universo visual: películas comerciales con películas más académicas, películas de un mismo realizador orientadas a audiencias distintas, películas con fotografías, fotografías de un mismo autor que formaron colecciones para circuitos de circulación diferentes. Es precisamente a través de la disposición de las imágenes que la autora identifica singularidades y convergencias, traza analogías, formula interrogantes e hipótesis y ensaya interpretaciones. La tesis que atraviesa de manera oblicua la constitución del corpus y su análisis es que el diálogo del registro fotográfico y fílmico ofrece mucho más que el análisis autónomo de cada uno de ellos.

El primer caso propone pensar el cine como tecnología de la visión en relación a un espacio especialmente preparado para la exhibición- las exposiciones internacionales- y la movilidad a través de tres filmes de Silvino Santos: No paiz das Amazonas, producido para ser exhibido en Rio de Janeiro en ocasión de la Exposición Internacional del Centenario de la Independencia de Brasil, Fragmentos da terra encantada y 1922. A exposiçao da Independência, dos cortos montados en 1970 a partir de la película Terra encantada filmada en Río de Janeiro durante el año de exhibición de la primera película citada. Por un lado, el análisis expone las particularidades de cada película; por otro, la experiencia de movilidad como elemento coincidente en la narrativa visual ya como un viaje al Amazonas, un tour urbano o desde la mirada móvil de los visitantes a la exposición internacional. El montaje de estas películas con las fotografías de Augusto Malta hace visible el contraste entre la ciudad en remodelación para el Centenario y la población que, por este mismo proceso, resulta excluida y relocalizada de Rio de Janeiro. Martins sostendrá que el 
lenguaje cinematográfico se consolidó como el medio de expresión de aquel Brasil moderno.

El segundo episodio toma como objeto de análisis el archivo visual (mapas, fotografías y película) de la séptima expedición al Amazonas de Hamilton Rice, un explorador estadounidense que sin credenciales académicas tuvo el apoyo de sociedades geográficas de Europa y Estados Unidos. Además de un sofisticado equipamiento técnico, la expedición de 1924-1925 estaba conformada por expertos en distintas áreas de conocimiento, entre ellos Silvino Santos en su calidad de fotógrafo y director de películas. Luciana Martins aquí hace dialogar dos películas filmadas por Santos (y sus respectivos montajes) en la misma expedición: Explorations in the Amazons Basin, dirigida a una audiencia estadounidense, y No rasto do Eldorado, proyectada en Brasil. La primera película, con el formato de una conferencia, tiene a Rice como el protagonista que presenta la región amazónica como una Terra Incognita a la espera de exploración y explotación; la segunda, con un lenguaje que se aleja de una narrativa pedagógica presenta una región "habitada, con textura y densidad".

El tercer caso examina dos contextos de visualización de las fotografías del misionero británico Kenneth Grubb: un contexto más público - sus libros orientados a una audiencia religiosa aunque su circulación excedió ampliamente ese circuito- y otro más privado - los álbumes fotográficos. La colección de imágenes se convierte en el objeto de análisis asumiendo que el orden de las imágenes reconfigura la propia imagen y sus sentidos. En este contrapunto entre registros públicos y privados se identifican dos regímenes de visibilidad bien diferentes. Asimismo, la autora añade otro nivel de significación al considerar los propios archivos como un nuevo contexto de visualización que constituyen sistemas de 
organización del conocimiento (Sekula, 1986) y de sentidos para las imágenes.

El cuarto episodio se centra en la cultura visual de la economía de las plantaciones del interior de Sao Paulo. La atención principal la tienen tres películas: Brazil gift, destinada a promover el consumo de café en Estados Unidos, Fazenda Santa Catharina y Companhia Docas de Santos, dos producciones brasileñas contemporáneas. El análisis de los modos de filmación traza analogías entre las trayectorias expuestas en las películas y las trayectorias comerciales, económicas, políticas y culturales del café. Luciana Martins examina estas tres películas con las imágenes que sugieren algunos textos del poeta suizo-francés Blaise Cendrars y una serie de fotografías que traen a la escena los esclavos, los indígenas y los inmigrantes. El montaje propuesto es la clave para enlazar la plantación a la matriz de una sociedad brutalmente excluyente y evidencia aquello que las tres filmaciones excluyeron.

El quinto caso es una indagación de las fotografías tomadas por Mário de Andrade en sus viajes a las regiones Norte y Nordeste de Brasil en 1927. La autora identifica en las fotografías los indicios de una mirada que construye un modo de conocer. Lejos de utilizar la fotografía como un registro mimético, el análisis sugerirá que Mário de Andrade desestabilizó las formas convencionales de ver a través de esas fotografías blanco y negro en las cuales las personas fotografiadas observan al fotógrafo, de una cámara situada a una proximidad extrema de los rostros (que provoca una experiencia más sensorial que visual) o con tomas desde puntos de vista inusuales que desorientan al observador.

El sexto episodio presenta un montaje que examina la proximidad existente entre registros visuales producidos para audiencias muy diferentes y con criterios de validación 
propios: por un lado, una película comercial -Last of the Bororos (1930-1931) de Aloha Baker, aventurera y realizadora canadiense; por otro, las fotografías y películas de Claude y Dina Lévi-Strauss tomadas en su viaje a Mato Grosso en 1935/1936. El análisis de Martins encuentra que el registro fílmico comercial y el corpus visual científico comparten una representación de los Bororos como indígenas aislados. La interpretación sugiere que esta coincidencia es el resultado de un proceso de colaboración de los Bororos en una extensa historia de contacto intercultural.

El libro se cierra con un breve análisis de la producción visual que se inaugura con el régimen autoritario de Getúlio Vargas y el férreo control del imaginario visual que se instaura con la finalidad de mostrar (hacia adentro y hacia afuera) una nación moderna. El montaje de este episodio expone la sintonía entre la producción fotográfica (Obra Getuliana) y fílmica (más de 200 filmes para ser distribuidos en escuelas, centros culturales, deportivos y de trabajadores, a los que se sumó también el Cine Jornal Brasileiro) realizada en Brasil con otras producciones visuales de origen estadounidense.

Algunos años atrás tuve la experiencia de tomar cursos sobre América Latina como estudiante de posgrado en un país anglosajón. Encontré una distancia enorme entre las problemáticas, las discusiones y la América Latina que se presentaba en la bibliografía disponible en inglés y "nuestra" literatura. Considero que la exploración entre estos dos registros visuales y los modos de entender e imaginar Brasil que ofrece este libro constituye un valioso estímulo intelectual tanto para una audiencia anglosajona como latinoamericana. Tal vez porque todo el libro se vuelve un desafío a imaginar montajes visuales para "descobrir -precisamente no sentido em que recusa os vínculos suscitados pelas semelhanças óbvias- vínculos que a observaçao direta é incapaz de discernir" (Didí-Huberman, 2013: 13). Creemos que, de manera análoga a la tarea realizada por Luciana Martins, la construcción de montajes 
visuales disonantes a los que presentan contemporáneamente los poderosos medios de comunicación nos permitirá leer y enfrentar los tiempos neoliberales que vuelve a atravesar América Latina.

\section{NOTAS}

${ }^{1}$ Pesquisadora do CONICET, Instituto de Geografía (UBA)

${ }^{2}$ Entre otros Andermann, J., \& Rowe, W. (Eds.). (2005). Images of power. Iconography, culture and the state in Latin America. New York, NY: Berghahn Books; Andermann, J. (2007). The optic of the State. Visuality and power in Argentina and Brazil. Pittsburgh, PA: University of Pittsburg Press; Dym, J., \& Offen, K. (2011). Mapping Latin America. A cartographic reader. Chicago, IL: University of Chicago Press.

\section{REFERÊNCIAS BIBLIOGRÁFICAS}

DIDI-HUBERMAN, Georges (2008). Cuando las imágenes toman posición. Madrid: Machado Libros.

DIDI-HUBERMAN, Georges (2013). Atlas ou a Gaia Ciência inquieta. Lisboa: KKYM+EAUM.

SEKULA, Allan (1986). The body and the archive. October 39, Winter: 3-64. 